\title{
Innovative Production Technology of Drinks from Grape Cryopowders
}

\section{Z A Yaralieva1, G I Kasyanov², P R Tagirova ${ }^{3}$, L N Shubina ${ }^{4}$, S A llyasova ${ }^{5}$, E Yu Mishkevich $^{6}$, A V Khrystyuk ${ }^{7}$, and M S Hasikhanov ${ }^{8}$}

${ }^{1}$ Dagestan State Technical University, Makhachkala, Russia

${ }^{2}$ Institute of Food and Processing Industry, Kuban State Technological University, Krasnodar, Russia

${ }^{3}$ Grozny State Oil Technical University named after Acad. M.D. Millionshchikov, Grozny, Russia

${ }^{4}$ Krasnodar Cooperative institute, Russian University of Cooperation, Krasnodar, Russia

${ }^{5}$ Dagestan State Technical University, Makhachkala, Russia

${ }^{6}$ Institute of Food and Processing Industry, Kuban State Technological University, Krasnodar, Russia

${ }^{7}$ ZAO Moscow Beer and Non-alcoholic Plant “Ochakovo”, Krasnodar branch No. 1, Krasnodar, Russia

${ }^{8}$ Grozny State Oil Technical University named after Acad. M.D. Millionshchikov, Grozny, Russia

Corresponding Author:

Z A Yaralieva

alievna5656@mail.ru

Received: 25 October 2019

Accepted: 15 November 2019

Published: 25 November 2019

Publishing services provided by

Knowledge

(c) Z A Yaralieva et al. This article is distributed under the terms of the Creative Commons.

Attribution License, which permits unrestricted use and redistribution provided that the original author and source are credited.

Selection and Peer-review under the responsibility of the AgroSMART 2019 Conference Committee.

\section{Abstract}

A technology, based on the production of wine beverages from grape cryopowders in the mountain-valley zone of the Republic of Dagestan, is proposed. The data on the vacuum microwave drying of grape raw materials and subsequent grinding in a cryomill are presented. The modes of grape raw material preparation and its subsequent dehydration and cryo-grinding, which provide the possibility of successful use in the dried state in the production technology of wine drinks, are proposed. The principal feature is the use of whole grapes as a raw material, with rinds and seeds. The physical and chemical indicators, the content of phenolic substances and the organoleptic indicators of wine beverages made according to the traditional technology and the beverage made from grape cryopowders were studied. A comparative assessment of beverages was made. It is established that vacuum microwave drying conduces to better preservation of the properties of raw materials and finished products. The organoleptic assessment showed that the wine drinks developed according to the proposed technology had a more intense color and a more pronounced flavor of sweetness and sourness than traditional wine beverages. The advantage of this technology is the ability to transport grape cryopowders in unregulated temperature conditions to any point close to the consumer and carry out the production of wine beverages there.

Keywords: grapes, cryopowders, wine beverage, drying technology, qualitative beverage composition.

\section{G OPEN ACCESS}




\section{Introduction}

One of the tasks of social and cultural development of the population in our country is the formation of the moderate use of high-quality wines and wine beverages. Numerous studies and observations of the nutritional structure of centenarians in the southern regions of the country have shown that 50--100 grams of dry wine a day have a positive effect on the body, since they are the source of a wide range of vitamins, minerals and antioxidants. However, in the northern regions of Russia, the use of strong alcoholic beverages prevails, resulting in a complex of negative factors that adversely affect both health and work. As is known, the production of wines and wine beverages is always concentrated in the places where the grapes are grown. Delivery of finished products in glass bottles, or in another form over long distances, is associated with significant financial costs, and climatic conditions limit the time for transporting wine in unheated vehicles. In this regard, there was a problem to process the grapes in such a way that the product could withstand long periods of storage and transportation, be high quality and have low weight. If necessary, based on this product, we can prepare wine beverages according to the classical technology of yeast fermentation.

When performing an analytical review of scientific and technical literature on the problem under study, the authors noted the increased interest of researchers in the problem of processing grapes grown in the regions of the North Caucasian and Southern Federal Districts for powdery food additives $[1,4,8,9]$. In the works of various authors the chemical composition of grapes grown in the mountain-valley and north-western zones of Dagestan are analyzing $[1,2,7]$. Among the existing methods for extending the shelf life of grape raw materials, cryogenic processing with the production of low-temperature cryopowders is highlighted $[3,6]$. When processing grapes for wine materials, attention was paid to the biochemical composition of grape varieties and new races of yeast $[5,8]$.

During the drying period of plant raw materials, the influence of the composition and thermal regimes on the change in the physical, chemical and antimicrobial properties of dry powders was taken into account [10]. To optimize the process of removing moisture from plant materials became possible using the methods of mathematical planning of the experiment [13]. To intensify the process of drying plant materials, for the production of powdered beverage, became possible through the use of foaming additives [14].

A part of the research is devoted to the assessment of the physical and chemical parameters of secondary resources for the processing of grapes and other fruits $[11,12]$. 
The implementation of this direction allows to increase production efficiency and reduce the cost of finished products.

\section{Formulation of the Problem}

To substantiate the expediency of processing whole grapes, with rinds and seeds, into cryopowders intended for the production of wine beverages according to the technology of classical yeast fermentation.

\section{Research Issues}

In carrying out the research, the issues of selection of grape varieties, zoned in local growing conditions, and the issue of preparation of whole grapes for drying, were solved.

\section{Purpose of the Study}

Development of an innovative technology for the production of beverages from highquality grape cryopowders using the classic yeast fermentation method.

\section{Research Methods}

When performing the work, the qualitative composition of raw materials and cryopowders was determined using analytical instruments and laboratory equipment of the Department of Food Technology and Expertise of Dagestan State Technical University. A part of the research was carried out with our participation in the laboratories of the Institute of Physics and the Mountain Botanical Garden of the Dagestan Scientific Center, Russian Academy of Sciences.

Determination of chemical and microbiological indicators of safety of raw materials and finished products was carried out in accordance with the technical guidelines of the Customs Union, current state standards for physical and chemical analysis methods: IR, UV and atomic absorption spectroscopy, gas-liquid and high-performance chromatography. 
The change in the temperature of the product during the drying process was determined using an infrared thermometer. The granulometric composition of the cryopowders was determined using the counter "Kul'tera TA-12".

The raw materials were Dagestan classic grape and raisin grape: Bor kara, Bayat kapy, Gulyabi Dagestan, Boryu raisins, Buday shuli, Boru koz raisins grown in the mountain-valley zone of Dagestan (Russia) in September 2016.

\section{Cryopowder Technology}

Grapes cryopowder was obtained according to the technology developed by the authors. The berries were separated from the ridges, crushed together with the rinds and seeds. The mass of raw material was metered into radio transparent plates with a layer thickness of 10--12 mm. The freezing of raw materials in plates was carried out by applying liquid nitrogen to the surface of the raw material at minus $160{ }^{\circ} \mathrm{C}$ for $10--15$ minutes and vacuum microwave drying of berries for $0.5 \mathrm{~h}$ to a humidity of $1.6-1.9 \%$.

The main feature of the heat treatment of grape raw materials in the electromagnetic field of ultra-high frequency is fast volumetric heating. At the same time, thermal energy is generated in the product itself due to its interaction with the microwave field. The heat generated in the product when it interacts with the electric field is distributed through the product due to convection or thermal conductivity.

Cryo-drying of pulp is carried out with the following parameters:

- Temperature at the stage of moisture removal by the "ice-steam" phase transition $(--180 . .--190) \pm 5{ }^{\circ} \mathrm{C}$. At the same time, the ice-steam phase transition removes 70--90\% of moisture.

- The material temperature at the drying stage is $(+30 \ldots+32) \pm 5{ }^{\circ} \mathrm{C}$.

- The final moisture content of the dried material is $6--7 \%$.

- The duration of the drying cycle -- 0.5 hours.

The dried material is a porous layer, easily destructible and turns into a powder mass. The resulting raw materials, in the form of cryopowder, are much less hygroscopic, and the particle size of such a powder is two orders of magnitude smaller compared to the pulp of the fruit.

The technology for producing sublimated powder from pulp ensures the safety of substances that form color formation: anthocyanins, chlorophylls, carotenoids, tannins 
and other polyphenols. At the same time, the concentration of phenolic compounds does not change and, in the future, the aroma of the beverage is enhanced.

Figure 1 shows the drying compartment using a vacuum microwave dryer.

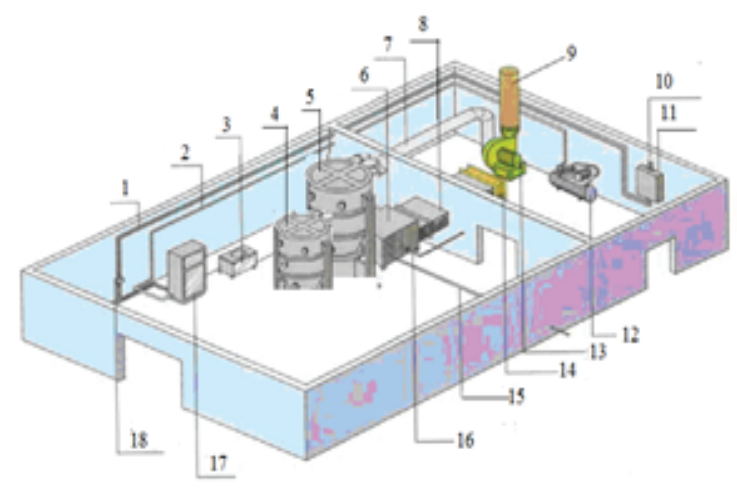

Figure 1: Shopfloor for the manufacture of cryopowders of fruit raw material: 1 powder line, 2 compressed air, 3 liquid trolley, 4 homogenizer, 5 vacuum microwave dryer, 6 cryo-mill, 7 air extract, 8 inlet air line, 9 eclifler, 10 powder control, 11 collector, 12 air compressor, 13 blower, 14 air vent, 15 cooling water pipe, 16 steam pipe, 17 control cabinet, 18 switch.

Table 1 shows the chemical composition of cryopowders obtained from grapes grown in the mountain-valley zone of Dagestan.

\subsection{Wine beverages technology}

The production of a wine beverage from grape cryopowder includes cryo-powder rehydration, sulfation, enzyme, pure yeast culture throwing, preliminary fermentation with maceration, pressing, sulfitation, fermentation, formation, stabilization of wine.

Rehydration is carried out by adding water to the sublimated powder in the ratio of 1 : (3--6) (1 kg of dry raw material to 3--6 I of water). To speed up rehydration, the product is mixed with water. The given level of the ratio of raw materials and water has been successfully used in the production of a wine beverage in a volume of 50 liters.

Then sulfitization and enzyme are carried out. Sulfur oxide is added to the resulting rehydrated preparation in the amount of 75 mg per 1 liter. Enzymes are added at the same stage.

After that, a pure yeast culture was laid (French yeast was used -- $25 \mathrm{~g} / 100 \mathrm{I}$ ). The process of fermentation and maceration is carried out for 5 days with slow stirring, with the transition of phenolic and dye substances to the wine material. The temperature regime of the fermentation process depends on whether the wine is expected to be obtained -- green or ripe. Then there is a separation of the pulp from the preparation by pressing it. 
TABLE 1: The chemical composition of cryopowders obtained from grapes grown in the mountain-valley zone of Dagestan.

\begin{tabular}{|c|c|c|c|c|c|c|}
\hline \multirow[t]{2}{*}{ Component Name } & \multicolumn{6}{|c|}{ The content of components in $100 \mathrm{~g}$ grapes varieties } \\
\hline & Bor kara & Bayat kapy & $\begin{array}{c}\text { Gulyabi } \\
\text { Dagestan }\end{array}$ & Boryu raisins & Buday shuli & $\begin{array}{c}\text { Boru koz } \\
\text { raisins }\end{array}$ \\
\hline Calorie, kcal & 327.4 & 333.5 & 331.5 & 326.6 & 331.3 & 286 \\
\hline Proteins, $g$ & 5.5 & 5.7 & 5.6 & 5.5 & 5.7 & 5.2 \\
\hline Fat, $\mathrm{g}$ & 2.6 & 3.5 & 2.7 & 2.6 & 2.9 & 2.5 \\
\hline Carbohydrates, g & 70.5 & 69.8 & 71.2 & 70.3 & 70.6 & 71.5 \\
\hline Dietary fiber, $\mathrm{g}$ & 9.8 & 9.6 & 9.8 & 9.7 & 9.8 & 9.7 \\
\hline Water, g & 11.6 & 11.4 & 10.7 & 11.9 & 11.0 & 11.1 \\
\hline Eicosanoic acid, g & 1.4 & 1.4 & 1.4 & 1.4 & 1.4 & 1.4 \\
\hline Ash, g & 2.5 & 2.5 & 2.5 & 2.5 & 2.5 & 2.5 \\
\hline SAFA, $g$ & 1.2 & 1.2 & 1.2 & 1.2 & 1.2 & 1.2 \\
\hline Ose \& biose, g & 39.6 & 39.6 & 39.6 & 39.6 & 39.6 & 39.6 \\
\hline Vitamin PP, mg & 0.5 & 0.5 & 0.5 & 0.5 & 0.5 & 0.5 \\
\hline$\beta$-carotene, mg & 36 & 36 & 36 & 36 & 36 & 36 \\
\hline Vitamin C, mg & 2.4 & 2.4 & 2.4 & 2.4 & 2.4 & 2.4 \\
\hline Vitamin $\mathrm{E}(\mathrm{TE}), \mathrm{mg}$ & 0.6 & 0.6 & 0.6 & 0.6 & 0.6 & 0.6 \\
\hline
\end{tabular}

Sulfation is carried out in a ratio of $20 \mathrm{mg}$ of sulfur oxide per liter. Further fermentation continues at ambient temperature for approximately one week. The formation of a wine drink occurs on average for about 28 days, then the stabilization of the drink, after which the bottling and storage are carried out.

A wine beverage was obtained from cryopowders with the following characteristics:

Table 2 shows the results of the determination of the numerical values of the physical and chemical characteristics of a wine beverage made according to the developed technology: active acidity, alcohol content, Total sugars, titratable acids and volatile acids, fat content, relative density, acid content in the finished wine.

Table 3 shows the content of phenolic components in wine beverages made according to the existing and new technology -- anthocyanins, catechins, leucoanthocyanins, tannins (polyphenols), flavonols and flavones. This group of biologically active substances primarily forms the color intensity of the finished wine and its taste. 
TABLE 2: Physical and chemical indicators of the wine beverage from grape cryopowder.

\begin{tabular}{l} 
Indicator \\
Active acidity of beverage $(\mathrm{pH})$ \\
Alcohol, \% vol. \\
Total: \\
- sugars, g/dm ${ }^{3}$ \\
- titratable acids, $\mathrm{g} / \mathrm{dm}^{3}$ \\
- volatile acids, $\mathrm{g} / \mathrm{dm}^{3}$ \\
- fat content, $\mathrm{g} / \mathrm{dm}^{3}$ (total/unreduced) \\
Relative density, $\mathrm{d}$ \\
The content in the finished wine: \\
Tartaric acid, g/l \\
Malic acid, g/l \\
Lactic acid, $\mathrm{g} / \mathrm{l}$ \\
Amber acid, g/l \\
The ratio of organic acids: \\
- amount (lactic acid + malic acid) \\
- tartaric acid / amount (lactic acid + malic \\
- tartaric acid / malic acid \\
\hline
\end{tabular}

\begin{tabular}{|c|}
\hline Norm \\
\hline $3.0-4.2$ \\
\hline$>9$ \\
\hline$<4.0$ \\
$>4.0$ \\
$<1.2$ \\
\hline $1.5-5.0$ \\
\hline$<5.0$ \\
\hline $0.5-2.5$ \\
\hline $0.25-1.0$ \\
\hline
\end{tabular}

\begin{tabular}{|c|c|}
\hline Result & 3.5+0.1 \\
\hline $10.97 \pm 0.06$ \\
\hline $5.4 \pm 0.2$ \\
$6.4 \pm 0.1$ \\
\hline $0.52 \pm 0.08$ \\
\hline $27.9 \pm 0.3 / 24.5 \pm 0.9$ \\
\hline $0.9993 \pm 0.0002$ \\
\hline $2.29+0.14$ \\
$1.61+0.32$ \\
\hline $0.51+0.06$ \\
1.33 \\
\hline
\end{tabular}

TABLE 3: The content of phenolic components in wine beverages made according to the existing and new technology.

Phenolic compounds, mg/l
Anthocyanins
Catechins
Leucoanthocyanins
Tannins (polyphenols)
Flavonols
Flavones

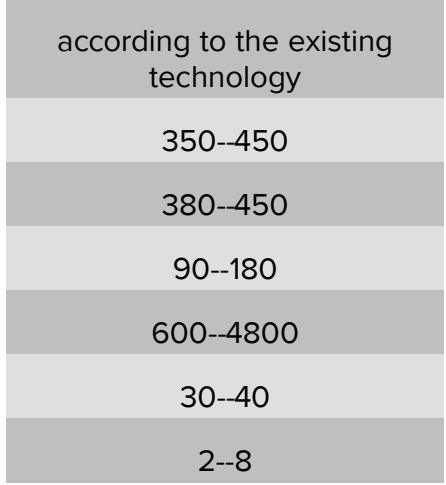

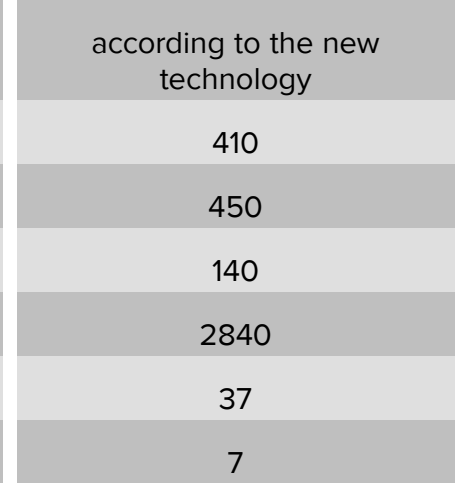

\section{Quality Indicators of Wine Beverages}

Table 4 shows the content of organic acids. Organoleptic characteristics of wine beverages made confirmed their high quality.

Figure 2 shows a diagram of the organoleptic assessment of wine beverages. 
TABLE 4: The content of organic acids in wine beverages.

Indicator
Tartaric acid, $\mathrm{g} / \mathrm{dm}^{3}$
Malic acid, $\mathrm{g} / \mathrm{dm}^{3}$
Lactic acid, $\mathrm{g} / \mathrm{dm}^{3}$
Amber acid, $\mathrm{g} / \mathrm{dm}^{3}$
amount (lactic acid + malic acid)
tartaric acid / amount (lactic
acid + malic acid)

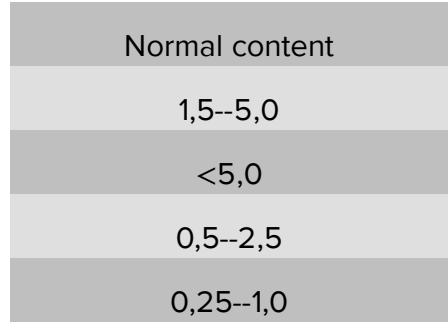

The ratio of organic acids:

The ratio of organic acids:

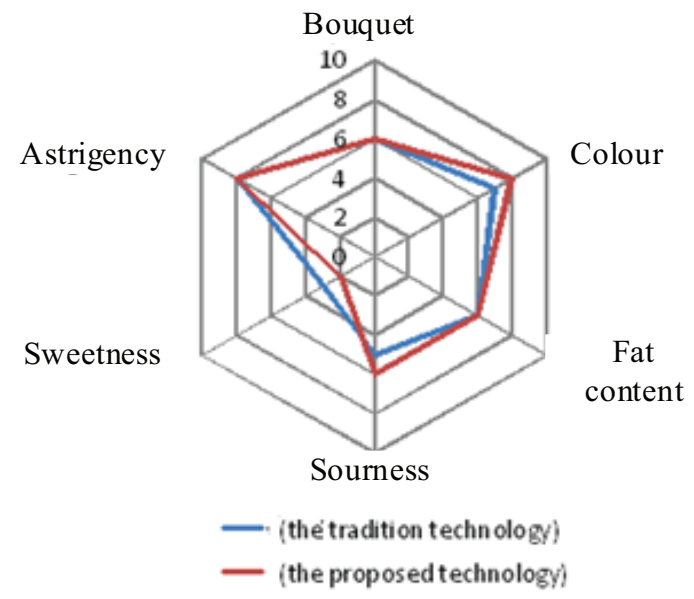

Research results

$$
2,29 \pm 0,14
$$$$
1,61 \pm 0,32
$$$$
0,51 \pm 0,06
$$

1,33

2,12
1,08

Figure 2: Diagram of the organoleptic assessment of wine beverages.

Color -- cherry with hues of elderberry, akin to the green wine. Bouquet -- wine, sharp when inhaled. The taste is not smooth, excessively tannin, with a slight bitterness. Overall impression: the product is wine, atypical, new.

\section{Consequences}

Dagestan classic grape and raisin grape: Bor kara, Bayat kapy, Gulyabi Dagestan, Boryu raisins, Buday shuli, Boru koz raisins, have a set of technological characteristics, allowing them to be used for the production of wine beverages not only by classical technology, but also subjected to vacuum microwave drying and cryo-grinding for subsequent use in winemaking throughout the year.

In this paper, the regime parameters of preparation, freezing and vacuum microwave drying of raw materials are theoretically substantiated and experimentally verified, allowing to preserve the native properties of raw materials in the production of wine 
beverages that are comparable in quality to beverages produced by traditional technology.

Fundamentally important point is that pulp with grape rinds and seeds was used as a raw material for crying powders, and their rehydration was carried out by adding light water in a ratio of 1: (3--6) to a sugar content of $20 \pm 2 \mathrm{~g} / \mathrm{l}$.

Microwave drying using the recommended operating parameters of the authors does not cause significant changes in physical and chemical parameters, as well as loss of phenolic substances of fruits and berries (anthocyanins, catechins, tannins, leucoanthocyanins, flavonols and flavones), preserving the organoleptic characteristics of the resulting wine beverages.

The complex of organic acids (tartaric, malic, lactic, amber) also does not undergo quantitative changes in the dried raw materials. This factor also ensures the achievement of taste, typical of high-quality red wine beverages from the grape varieties used in the work.

The proposed technology for the production of wine beverages can be implemented in regions where grapes, in principle, cannot be grown, based on the production of wines from sublimated grape raw materials. This will reduce transport costs for delivering the product to consumers. Another undoubted advantage is the possibility of producing wine beverages without reference to the time of harvest.

\section{Conclusion}

Thus, the studies performed by the authors confirmed the possibility of obtaining grape wine drinks from cryopowders. However, in order to achieve optimal parameters both in the field of obtaining sustainable quality indicators of wine drinks and expanding the range, and in the direction of finding rational regime parameters of preliminary freezing and subsequent drying, further research is needed. In particular, the freezing regimes (process speed and final temperature), the sublimation temperature and the amount of moisture associated with it, which is removed by the ice-steam phase transition, are interrelated with the quality of the dried materials and the technical parameters of the drying devices. These and other questions should be the subject of further research. 


\section{References}

[1] Abdullabekov, R.A. (2016). The use of grape raw materials as a source of dietary supplements in conditions of taxiways. Mining agriculture, no. 1, pp. 153--158.

[2] Vlasova, O.K., Bakhmulaeva, Z.K., Magadova, S.A. (2017). The formation of the chemical composition of grapes in the north-western zone of Dagestan. Winemaking and viticulture, no. 1, pp. 27--30.

[3] Kasyanov, G.I., Yaralieva, Z.A., Akhmedov, M.E. (2018). Fruit and berry cryopowder technology. Krasnodar: Ecoinvest, $155 \mathrm{p}$.

[4] Kustova, I.A., Makarova, N.V. (2015). Comparative analysis of the chemical composition and antioxidant activity of grapes of several varieties: world level and own research. Magarach. Viticulture and winemaking, no. 3, pp. 76--77.

[5] Lisovets, U.A., Ageeva, N.M. (2015). The influence of new races of active dry yeast on the chemical composition of white table wine materials. Eurasian Union of Scientists, no. 10-2(19), pp. 81--83,

[6] Nadykta, V.D., Shcherbakova, E.V., Olkhovatov, E.A. (2017). Technology of powdered food additives. Polythematic network electronic scientific journal of the Kuban State Agrarian University, no. 131, pp. 659--671.

[7] Ramazanov, O.M., Ramazanov, Sh.R., Magomedov, M.G. (2015). The chemical composition of table grapes in the conditions of the mountain -- valley zone of Dagestan. Bulletin of Michurinsky State Agrarian University, no. 3, p. 35--40.

[8] Studennikova, N.L., Kotolovets, Z.V., Razgonova, O.V. (2016). Study of the chemical and biochemical composition of ripe berries of new grape varieties ifigenia and pearls under cultivation in different zones of the Crimea. News of Agricultural Science of Tauris, no. 6(169), pp. 11--17.

[9] Khanikaev, D.N. (2017). The chemical composition of grapes of different varieties of grapes in the conditions of North Ossetia-Alania. News of Gorsky State Agrarian University, vol. 54, no. 3, pp. 165--169.

[10] Chandrasekar, V., Gabriela, J., Kannan, K., Sangamithra, A. (2015). Effect of foaming agent concentration and drying temperature on physicochemical and antimicrobial properties of foam mat dried powder. Asian J. Dairy Food Res., vol. 34, pp. 39-43.

[11] Hasanah, H., Chong, G., Suzana, S. (2014). Comparison of physicochemical analysis and antioxidant activities of Nigella sativa seeds and oils from Yemen, Iran and Malaysia. J. Sci., vol. 43, pp. 535--542. 
[12] Kasyanov, G., Davydenko, T. (2017). High-tech processing of secondary resources of winemaking. Food science and technology, vol. 1, pp. 75--80.

[13] Patil, V., Chauhan, A.K., Singh, R.P. (2014). Optimization of the spray-drying process for developing guava powder using response surface methodology. Powder Technol., vol. 253, pp. 230--236.

[14] Production of Nigella sativa Beverage Powder under Foam Mat Drying Using Egg Albumen as a Foaming Agent. (2017). Beverages, no. 3, pp. 9. DOI:10.3390/beverages3010009 